\title{
Comparison of biocidal and sporicidal effects of spark discharge plasma and mercury-vapor low pressure lamp radiations
}

\author{
Irina P. Ivanova ${ }^{1}$, Igor M. Piskarev ${ }^{* 2}$, Svetlana V. Trofimova ${ }^{1}$ \\ ${ }^{1}$ Nizhny Novgorod State Medical Academy, 603005, Nizhny Novgorod, Minin and Pozharsky Square, \\ 10/1, Russia \\ ${ }^{2}$ Skobeltsyn Institute of Nuclear Physics, Moscow State University, 119234, Moscow, Leninskie Gory, \\ MSU NP, Russia
}

\begin{abstract}
In this work it was shown that the inactivation micromycets spore (fungi) to hot plasma radiation of self-sustained spark discharge on air is much more effectively than UVradiation mercury-vapor lamp. Though the discharge electrical power is 15 times and UVphotons flux 430 times more for mercury lamp than for spark discharge. Discussed method inactivation is very simple.
\end{abstract}

\section{Key words: micromycet inactivation, spore, hot plasma radiation, UV-mercury lamp}

\section{INTRODUCTION.}

The germicidal effect of UV-radiation is well known. It due to photon energy absorbtion by DNA molecules, as result the chemical reactions are initiated, which damage these molecules [1]. The surface sterilization is important and needful procedure, which is used in medicine, food production and others. One of the methods microorganism inactivation is treatment to UV-radiation. The absorption spectrum of DNA molecules is continues from wavelength 180 up to $300 \mathrm{~nm}$ with broad maximum at $190-200$ and $260 \mathrm{~nm}$ [2]. The radiation spectrum of mercury-vapor low pressure lamp (MVLPL) is narrow line $253.7 \mathrm{~nm}$, its wavelength is in region maximum absorption of DNA $260 \mathrm{~nm}$. Therefore the mercury (quartz) lamp has biocidal effect. The source of UV-radiation can be electric discharge plasma [3]. If plasma is cold, it can directly contact with treated surface, don't damage surface. The sterilization effect in this case is achieved by combined action of discharge plasma radiation and active particles, generated in liquid and gas phase (radicals, ions, neutrals) [4].

If plasma is hot, direct contact with treated surface leads to its heat damage, therefore hot discharge plasma must be on safe distance, and germicidal effect is provided by plasma radiation. The plasma cord heated up to high temperature radiates as black body. The radiation spectrum of black body is continuous; the maximum position is determined by cord temperature. This spectrum can be consensual in shape with absorption spectrum of DNA, and then germicidal effect of electric discharge increases.

Continuous arc discharge has limitation on power, as electrodes can melt. Pulse spark discharge allows to heat a plasma cord up to more high temperature without electrode melting, than arc. With temperature increasing the maximum of radiation spectrum move in direction of shorter wavelength. The DNA absorption maximum at $190-200 \mathrm{~nm}$ frequently is more significant, then at $260 \mathrm{~nm}$ [2], therefore the germicidal radiation effect increase with decreasing wavelength. Authors of this work developed the radiation hot plasma generator on the base of self-sustained spark discharge (SD) on air. The aim of this work is to compare the biocidal and sporicidal effects of SD and mercury-vapor low pressure lamp radiations (MVLPL).

\section{MATERIALS AND METHODS}

\subsection{Radiation sources: spark discharge (SD)}

Discharger with stainless still rod electrode $2 \mathrm{~mm}$ diameter formed self-sustained spark discharge. Length of electrodes was not more than $45 \mathrm{~mm}$. Spark gap was $\sim 3 \mathrm{~mm}$, breakdown voltage of gap was $6-6.5 \mathrm{kV}$. Parallel discharge gap is capacitor $3.3 \mathrm{nf}, \mathrm{V}=10 \mathrm{kV}$. Value of capacitor was chosen to provide maximum chemical effects in distilled water. Capacitor was charged via ballast resistor $10 \mathrm{M} \Omega$ from power supply $11 \mathrm{kV}$. For this electrical parameters arose selfsupporting spark discharge with frequency $10 \mathrm{~Hz}$, pulse duration $100 \mu \mathrm{s}$, front duration $-0.1 \mu \mathrm{s}$. Pulse energy was $5.910^{-2}$ J. Spark discharge was source of UV-radiation continuous spectrum with maximum at $\lambda=220 \mathrm{~nm}$. Gas, heated in spark gap, radiate as black body, maximum position is determined by spark cord temperature. Maximum of spectrum is dislocated when gas cooling in direction of more long wavelength. Active particles (radicals) are created in water under action of UVradiation. Photons flux of UV-range on the treated samples ( $1 \mathrm{~cm}$ distance from discharge gap) was $1.2610^{-10} \mathrm{M} \mathrm{cm}^{-2} \mathrm{~s}^{-1}$. 


\subsection{Mercury-vapor low pressure lamp (MVLPL)}

Mercury-vapor low pressure lamp DBK-9 was used as UV-radiator, giving monochromatic line $253.7 \mathrm{~nm}$. Arc discharge burnt in lamp, the discharge current was $170 \mathrm{~mA}$. Electric power of lamp was $9 \mathrm{~J} \mathrm{~s}^{-1}$. The radiation of heated plasma cord, as black body, gives some contribution, but it was negligible. The main role play mercury line $253.7 \mathrm{~nm}$. Photon flux in the place of treated sample ( $3 \mathrm{~cm}$ from lamp) was $5.410^{-8} \mathrm{M} \mathrm{cm}^{-2} \mathrm{~s}^{-1}$. When compare energetic characteristics sources of radiation we see, power mercury lamp is 15 times more than SD, photon flux $253.7 \mathrm{~nm}$ is 430 times more, than UV-photons flux from SD, but average wavelength from SD is essentially shorter than $253.7 \mathrm{~nm}$.

\subsection{Biological samples}

The experiment was carried on bacterial strains of antibiotic-resistant gram-positive microorganisms of Staphylococcus aureus 5913 and gram-negative microorganisms of Escherichia coli 775-3. Bacterial strains were taken from the museum of the Departament of Microbiology and Immunology, Nizhny Novgorod State Medical Academy. For analyses there were pre-prepared daily culture. Then bacterial cells were resuspensed in Hanks' solution up to concentration of (10 15) $10^{6}$ cells per $1 \mathrm{ml}$.

In experiment there was assessed the bacterial cell growth inhibition after plasma irradiation. Microorganism suspension, $4 \mathrm{ml}$ in volume, was exposed to plasma radiation within 2, 5, 10, 15, 30, $60 \mathrm{~s}$. The plating in Petri dishes on stiff agar was carried out. After that the samples were placed in a oven for a day at $37^{\circ}$. Biocidal effect of plasma radiation was estimated by the number of colony-forming units (CFU).

Micromycete cultures (Alternaria alternata BKM F-1120, Aspergillus Niger BKM F-1119, Chaetomium Globosum BKM F-109, Penicillium Chrysogenum BKM F-245) were taken from All Russia collection of microorganisms. Spores suspension in water with concentration $(2-4) 10^{6}$ cells in $1 \mathrm{ml}$ was prepared. Samples in volume 4 ml were treated to SD during 1, 7.5 and 10 minutes, and to MVLPL during 10 minutes. After that the plating in Petri dishes on Czapek Doks media was carried out. Then the samples were placed in a oven for 3 days at $27^{\circ} \mathrm{C}$. The number of CFU estimated sporicidal effect of plasma radiation.

The data obtained in the experiment were statistically processed using application program package EXCEL, Statistica 6.0. Statistical significance of the average differences was determined using Mann-Whitney test.

\section{RESULTS}

Parameters of spark discharge were chosen so as to provide maximum chemical effect in treated distilled water [5]. In works [5, 6, 7] characteristics (yields) of active particles, nascent in water under action of this discharge were determined, and, for comparison, yields the same particles by MVLPL. Initial active particles yields are given in table 1. Main active particles for both irradiators are $\mathrm{HO}_{2}{ }^{\bullet}$ radicals, yields of which for SD and MVLPL are practically equal. In course of water irradiation by SD take place significant $\mathrm{pH}$ decreasing, as by MVLPL irradiation the $\mathrm{pH}$-value change is small. By SD 14 products in water are created: $\mathrm{HO}_{2}{ }^{\bullet}, \mathrm{OH}^{\bullet}, \mathrm{H}_{2} \mathrm{O}_{2}, \mathrm{O}^{\bullet}, \mathrm{O}_{2}{ }^{--}, \mathrm{O}_{3}, \mathrm{~N}_{2} \mathrm{O}, \mathrm{NO}, \mathrm{NO}_{2}, \mathrm{~N}_{2} \mathrm{O}_{3}, \mathrm{~N}_{2} \mathrm{O}_{4}, \mathrm{HNO}_{2}, \mathrm{HNO}_{3}$, $\mathrm{ONOO}^{-}$, for many of it the stationary concentration is in limits $10^{-4}-10^{-6} \mathrm{M} \mathrm{l}^{-1}$ [7]. Ozone and hydrogen peroxide, playing usually crucial role during sterilization process were determined, but its concentrations are vary small to play significant role.

UV- and IR-spectra of chemicals, produced in water and gas phase were measured [6]. In discharge gas phase a compounds of nitrogen are created, which contain $\mathrm{CN}$ - and $\mathrm{NH}$ - groups, as well organic compounds with $\mathrm{CH}-$ and $\mathrm{CC}$ groups. The more appreciably is nitrozamine production. Traces of compounds, containing metals, which could evaporate due to electrode heating, don't detected. Absence of electrode evaporation is result low discharge energy: $5.910^{-2} \mathrm{~J}$. The survivability of microorganisms after irradiation to SD and MVLPL are investigated. Transformations in lipids and proteins during irradiation in our experiment have an influence on living cell, which consist out of these molecules. Lipids oxidation reduces the protective properties of biological membranes, proteins oxidation and modification destroys cell function. Variation of $\mathrm{pH}$ outside the cell provided that intracellular $\mathrm{pH}$ value wills the same lead to appearance a difference of potentials, applied to membrane. Value $\Delta \mathrm{pH}$ according Nernst equation determines difference of red-ox potentials: $\Delta \varphi=\varphi_{0}-\Delta \mathrm{pH} \cdot 60(\mathrm{mV})$. This difference of potentials can destroy membrane functions.

Radiation spectrum of SD is broad and more similar to absorption spectrum of DNA, than spectrum of MVLPL. Pulse mode of SD radiation provides higher instantaneous active particles concentration that enhances the chemical reactions rate under SD as compared with MVLPL.

The comparison of germicidal effect SD and LPML shows in table 2, where presents a number of Colony-Forming Units (CFU) for S.aureus и E.coli depending on time treatment. It is seen for both kinds of microorganisms the time of 10 times CFU decrease under LPML is about 2 seconds. For SD time of the same CFU decrease is 60 seconds. It is not surprising as photons flux in UV region of MVLPL spectrum is 430 times more than SD spectrum.

Radiation dose required 10 times bacteria inactivation for SD is $30-50$ times more than for MVLPL, i.e. energy consumption for inactivation S.aureus and E.coli to SD is essentially more than to MVLPL. Spark discharge radiation is pulse, frequency $10 \mathrm{~Hz}$. Pulse repetition time is $100 \mathrm{~ms}$, but pulse duration is $100 \mu$ s. I.e. $99.9 \%$ full time SD treatment radiation is absent. During $600 \mathrm{~s}$ treatment radiation acts only $0.6 \mathrm{~s}$. Therefore a possible mechanism of energetic efficiency decrease to SD can be adaptation processes in pause between radiation pulses [8]. 
The deactivation by means of MVLPL for microorganisms spore is inefficient. Microscopic fungi (micromycetes, spores) are one of these microorganisms. Example is in table 3, where is presented a number of CFU in control (not treated) probe and after treatment to SD and MVLPL for 4 kinds of microscopic fungi, micromycetes (A. Alternata, A. Niger, Ch. Globosum, P. Chrysogenum). The count of CFU was made in 3 days incubation at $27^{\circ} \mathrm{C}$ after sowing and irradiation. It is seen in samples treated with SD during 10 minutes micromycets colony not found, while after treatment during the same times with MVLPL spore survivability compared to control is still the same. Energy expense for spore 10 times inactivation by means $\mathrm{SD}$ is $0.3-3.5 \mathrm{~J} \mathrm{~cm}^{-2}$ for various spores. This value should compare with MVLPL, when at energy expense $50 \mathrm{~J}$ $\mathrm{cm}^{-2}$ there is no effect.

\section{CONCLUSION.}

In this work it was shown the treatment of micromycets spore to spark discharge give essentially more sporicide effect compared to low pressure mercury-vapor lamp, but energy expense remain considerable. The mechanism of sporicide action is complicated. The realization of method is very simple.

\section{REFERENCES}

[1] J.F. Rabek. Experimental methods in photochemistry and photophysics (John Wiley \& Sons, New York, 1982).

[2] R.V. Bensasson, E.J. Land, T.G. Truscott. Flash photolysis and pulse radiolysis: contributions to the chemistry of biology and medicine (Pergamon Press, New York, 1983).

[3] Alexander Fridman. Plasma Chemistry (Cambridge University Press, Cambridge, 2008).

[4] Y.Z. Tang, X.P. Lu, M. Laroussi, F.C. Dobbs. Plasma Processes and Polymers. 5. 552 - 558. (2008).

[5] I.M. Piskarev, I.P. Ivanova, S.V. Trofimova, N.A. Aristova, High Energy Chemistry. 46, No 5, 343 - 348 (2012).

[6] I.P. Ivanova, S.V. Trofimova, N. Karpel Vel Leitner, N.A. Aristova, E.V. Arkhipova, O.E. Burkhina, V.A. Sysoeva, I.M. Piskarev, Modern Technologies in Medicine. No 2, 12 - 18 (2012).

[7] I.M. Piskarev, I.P. Ivanova, S.V. Trofimova. High Energy Chemistry. 47. No 2. $62-66$ (2013).

[8] D.L. Nelson, M.M. Cox. Lehninger principles of biochemistry $-5^{\text {th }}$ ed. (W.H. Freeman \& Co, New York, 2008)

Table 1. Initial yields of active particles (experiment) $[5,6,7]$.

\begin{tabular}{|l|l|l|}
\hline Agent & SD & MVLPL \\
\hline $\mathrm{HO}_{2}{ }^{-}$ & $(1.2 \pm 0.3) 10^{-6} \mathrm{M}(1 \mathrm{~s})^{-1}$ & $(1.1 \pm 0.5) 10^{-6} \mathrm{M}(1 \mathrm{~s})^{-1}$ \\
\hline $\mathrm{NO}_{3}{ }^{-}+\mathrm{NO}_{2}^{-}$ & $(5.8 \pm 1.6) 10^{-7} \mathrm{M}(1 \mathrm{~s})^{-1}$ & $(3.4 \pm 1) 10^{-9} \mathrm{M}(1 \mathrm{~s})^{-1}$ \\
\hline $\mathrm{NH}_{4}{ }^{-}$ & $(1.7 \pm 0.5) 10^{-10} \mathrm{M}(1 \mathrm{~s})^{-1}$ & $(2.5 \pm 1.5) 10^{-8} \mathrm{M}(1 \mathrm{~s})^{-1}$ \\
\hline
\end{tabular}

Table 2. Number of colony-forming units (CFU) in control (without treatment) and after treatment during time $t$ (s) to SD and MVLPL.

\begin{tabular}{|c|c|c|c|c|}
\hline \multirow{2}{*}{$\begin{array}{l}\text { Time treatment, } \\
\mathrm{t}, \mathrm{s}\end{array}$} & \multicolumn{2}{|c|}{ Staphylococcus Aureus } & \multicolumn{2}{|c|}{ Escherichia coli } \\
\hline & SD & MVLPL & SD & MVLPL \\
\hline Control & $1072 \pm 100$ & $1072 \pm 100$ & $984 \pm 100$ & $984 \pm 100$ \\
\hline 2 & $1025 \pm 100$ & $96 \pm 10$ & $984 \pm 100$ & $56 \pm 6$ \\
\hline 5 & $846 \pm 90$ & $90 \pm 10$ & $980 \pm 100$ & $50 \pm 6$ \\
\hline 10 & $924 \pm 90$ & - & $829 \pm 90$ & - \\
\hline 15 & $986 \pm 90$ & - & $805 \pm 80$ & - \\
\hline 30 & $282 \pm 30$ & - & $504 \pm 50$ & - \\
\hline 60 & $34 \pm 5$ & - & $283 \pm 30$ & - \\
\hline $\begin{array}{l}\text { Desactivation dosage in } 10 \text { times, } \mathrm{mJ} \\
\mathrm{cm}^{-2}\end{array}$ & $86^{* *}$ & $2.6^{*}$ & $100 * *$ & $2^{*}$ \\
\hline
\end{tabular}

*) - article [3].

$* *)$ - this work.

Table 3. Evaluation of sporicidal effects. Number of CFU in control and after irradiation to SD and MVLPL in 3 days incubation.

\begin{tabular}{|l|r|r|r|r|r|c|}
\hline \multirow{2}{*}{ Kind of micromycete } & \multicolumn{4}{l|}{ SD } & \multicolumn{3}{l|}{ MVLPL } \\
\cline { 2 - 7 } & Control & 1 min & 7.5 min & 10 min & \multicolumn{1}{l|}{ Control } & 10 min \\
\hline A.Niger & $147 \pm 7.5$ & $49.3 \pm 2.5$ & $27 \pm 2$ & 0 & $40.7 \pm 1.5$ & $39.7 \pm 1.5$ \\
\hline A.Alternata & $23 \pm 3.4$ & $6 \pm 5.6$ & 0 & 0 & $19.7 \pm 1.5$ & $17.3 \pm 1.5$ \\
\hline Ch.Globosum & $13.3 \pm 5.7$ & 0 & 0 & 0 & $30.0 \pm 5.6$ & $27.0 \pm 2.6$ \\
\hline P.Chrysogenum & $71.3 \pm 4.9$ & $51.3 \pm 6.6$ & $0.7 \pm 0.5$ & 0 & $15.7 \pm 2.1$ & $10.3 \pm 1.5$ \\
\hline
\end{tabular}

